\title{
Motyw nieokreśloności Rosji jako element dziewiętnastowiecznych narracji politycznych
}

\begin{abstract}
Streszczenie: Dziewiętnastowieczna popularność oraz wieloznaczność rozmaitych wariantów motywu nieokreśloności Rosji przyczyniły się do upowszechnienia poglądu o nieusuwalnym jej niedopasowaniu do Zachodu. Na kanwie tego typu wyobrażeń długo narastały przesłanki niechęci pomiędzy obiema przestrzeniami kulturowymi. Na tym tle widać częściowo, dlaczego w stosunkach Rosjan z narodami Europy, mimo nie tak znów rzadkiej, wzajemnej fascynacji, wielokrotnie górę brały konflikty interesów, animozje i zakłopotanie związane z niełatwą przeszłością oraz dystans kulturowy. Wszystkie wymienione bariery - w powiązaniu z gwałtownym przyspieszeniem procesów historycznych, w tym z intensyfikacją kontaktów międzynarodowych - sprzyjały i nadal sprzyjają kreowaniu strachu, nieufności, niefortunnych wypowiedzi, urażonej dumy, a niekiedy nawet wzgardy i chęci odwetu.
\end{abstract}

Słowa kluczowe: Rosja jako przedmiot narracji politycznych, motyw nieokreśloności Rosji, Astolphe de Custine, Piotr Czaadajew

$\mathbf{W}$ XIX stuleciu Europa stanowiła przestrzeń wielopłaszczyznowego sporu dotyczącego walorów nieokreśloności. Z jednej strony niejasność, nieuchwytność, niespójność, nieklasyczność były cenione (np. romantyzm), z drugiej pogardzane (np. pozytywizm). W związku z tym trudno się dziwić, że wieloźródłowość i wielonurtowość kultury rosyjskiej fascynowała oraz przyciągała coraz to nowych podróżników. Zarazem jej niekanoniczność prowokowała, by postrzegać ją jako nieokrzesaną, żywiołową i przez to groźną, a nawet odpychającą.

Ambiwalencję wobec Rosji sygnalizowano bardzo często - nierzadko w sposób pogłębiony, wraz z szerokim uzasadnieniem. Mistrzostwo w tej dziedzinie - o ile bierze się pod uwagę kryterium artyzmu i wyrafinowanie argumentacyjne - osiagnął markiz Astolphe de Custine (1790-1857) (nt. życia i twórczości markiza, a także recepcji jego głównej pracy zob. np. Мильчина; Muhlstein, 2001; Кожинов; Мяло). Jego relacja z niedługiego, lecz intensywnego pobytu w państwie Romanowów, nie tylko odniosła bezsprzeczny sukces wydawniczy. Z czasem stała się również pracą klasyczną, przywoływaną i komentowaną, wychwalaną i ganioną przez wielu znawców kultury rosyjskiej.

Niemniej - zgodnie z deklaracją samego de Custine'a - przedstawiona przez niego charakterystyka Rosji nie była dla niego najistotniejsza. Wiele przemawia za tym, iż przebogatą prezentację rosyjskiej nieokreśloności markiz traktował jako środek, a nie cel sam w sobie - na jej tle chciał dobitniej odmalować problemy własnego narodu, ukazać dylematy, z którymi borykało się ówczesne społeczeństwo francuskie. Jednak - o, ironio - czytelnicy właściwie nie przejęli się i nadal rzadko jedynie przejmują motywacjami, z jakimi do pisania o Rosji przystępował de Custine. Jego praca - po 
dziś dzień - jawi się jako interesująca przede wszystkim ze względu na zawartą w niej mieszaninę podróżniczych wyobrażeń dotyczących Rosjan, a nie Francuzów.

Powyższe uwagi współgrają z opinią Ireny Grudzińskiej-Gross (ur. 1946), która zauważyła, że w La Russie en 1839 „mamy opis i analizę Rosji, ale także są w niej poruszone najbardziej palące i bolesne sprawy porewolucyjnego społeczeństwa francuskiego" (Grudzińska-Gross, 2000, s. 27). Natomiast Gustaw Herling-Grudziński (1919-2000) podobny sąd wyraził w Dzienniku pisanym noca. W jego świetle, markiz napisał pracę, która przede wszystkim miała być , anatomią despotyzmu, bezlitosną, dokonaną ostrym lancetem, nieodopartą w swoim przewodzie obserwacyjnym i myślowym". De Custine'owi - w mniemaniu G. Herlinga-Grudzińskiego - nie chodziło przy tym jedynie o stworzenie traktatu filozoficzno-politycznego, lecz również o wyprowadzenie możliwie konkretnych porad oraz przestróg dla swoich rodaków. Markiz, pisząc o Rosji, miał usiłować przestrzec ich przed pokusą pochylenia głów przed jakimkolwiek despotą. Tyrania - uważał G. Herling-Grudziński - w opinii de Custine'a, zawsze jest zła - choć różnice pomiędzy jej historycznymi odmianami miewają istotny charakter („,We Francji tyrania rewolucyjna jest przejściowym złem. W Rosji tyrania despotyzmu jest rewolucją permanentną") (Herling-Grudziński, 1989, s. 7).

Motywację, o której mowa w wypowiedziach I. Grudzińskiej-Gross oraz G. Herlinga-Grudzińskiego, markiz bez ogródek wyłożył już we „Wstępie” swojej pracy: „Pojechałem do Rosji by znaleźć tam argumenty przeciw rządom reprezentacyjnym, wracam z niej jako zwolennik konstytucji”. A zatem, w świetle wyraźnych deklaracji samego de Custine'a, podróż po kraju carów to dla niego przede wszystkim wyprawa w celu znalezienia argumentów, przydatnych w roztrząsaniu dylematów politycznych nurtujących jego ziomków. Przybliżając zatem przemyślenia oparte na swoich obserwacjach, zmierza podróżnik ku wnioskowi, iż „Rządy mieszane nie najbardziej sprzyjają aktywności, ale starzejące się ludy mają mniejszą potrzebę działania, a taki rząd właśnie najbardziej wspomaga produkcję i przynosi ludziom największy dobrobyt i zamożność, a przede wszystkim taki rząd właśnie budzi największą aktywność myślową w sferze pomysłów praktycznych; wreszcie uniezależnia obywatela, nie na drodze uwznioślenia uczuć, ale przez działanie praw: oto bez wątpienia wielkie zadośćuczynienie za wszelkie niedogodności. W miarę poznawania straszliwych i osobliwych rządów uprawomocnionych, a może nawet wprowadzonych przez Piotra I, lepiej zrozumiałem wagę misji, którą mi powierzył przypadek" (cyt. za Herling-Grudziński, 1989, s. 9).

W przytoczonym cytacie na szczególną uwagę zasługuje zestawienie Francji - kraju starzejącego się, z Rosją - krajem młodym. Na pozór niewinny kontrast, krył w sobie w XIX wieku bagaż wyobrażeń, spośród których wiele można by uznać za uprzedzenia. Starzejąca się Francja - wynika to z narracji de Custine'a - jest zorganizowana, młoda Rosja - nie, pierwsza jest więc ostoją cywilizacji, druga reprezentuje barbarzyństwo. Stąd następujący wniosek - de Custine, w duchu Monteskiusza, usiłuje przekonywać, że ułożeni Francuzi winni bronić się przed rządami despotycznymi, by nie upodobnić się do nieokrzesanych Rosjan.

Stosunek markiza do Rosji nie był w pierwszej połowie XIX niczym wyjątkowym. Nie wynikał przy tym z empirycznie uzasadnionej niechęci wobec dominującej nacji imperium rosyjskiego. Rzeczywiste kontakty de Custine’a z Rosjanami były na ogół bardzo układne, a nade wszystko powierzchowne. Uprzedzenia, które markiz bez waha- 
nia wyrażał w pracy, wynikały nie z doświadczeń personalnych, lecz z wyobrażeń, podsycanych lekturą zachodnioeuropejskiej literatury, a także kilkumiesięczną, z pewnością silnie emocjonująca, obserwacją imperialnych elit.

Zgodnie z uwagą I. Grudzińskiej-Gross, należy również pamiętać, że w czasach, gdy markiz pisał La Russie en 1839, „Istniała przecież imaginacyjna mapa świata, w której centrum znajdowało się głębokie rozszczepienie najpierw na Południe i Północ, potem na Wschód i Zachód, a każda $\mathrm{z}$ wyodrębnionych części miała określony zespół właściwości" (Grudzińska-Gross, 2000, s. 84). Markiz partycypując w użytkowaniu tej mapy, w oparciu o nią konstruował swój ogląd XIX-wiecznej rzeczywistości politycznej. Ta sieć przekonań, wyrosłych w sporej mierze na gruncie refleksji oświeceniowej, stanowiła wygodne narzędzie porządkowania świata, a także doskonale współgrała z wartościami oraz interesami, które de Custine posiadał i w obronie których występował ${ }^{1}$.

Jego praca jawi się zatem jako książka Francuza pisana dla Francuzów - wyraźnym jest zarazem, że autora i odbiorcę łączyć miało założenie, w świetle którego są przedstawicielami narodu szczycącego się kulturą wielce wysublimowaną. Jej subtelność - w świetle szeroko rozpowszechnionych wówczas przekonan - formowała się przez długie stulecia, przepełnione okrucieństwem i zabobonem. Niemniej - a przekonanie to markiz mógł czerpać z prac niejednego luminarza francuskiego oświecenia - łańcuch historycznych doświadczeń, nawet tych najbardziej traumatycznych, nie był bezsensowny. W toku burzliwych dziejów kolejne pokolenia miały odkrywać coraz to bardziej wyrafinowane idee, w oparciu o które kształtował się sposób życia Francuzów, w szczególności typowy dla nich styl uprawiania nauk i sztuk. W ten sposób gruntowało się wrażenie - de Custine w poważnym stopniu mu ulegał - iż najwybitniejsze wytwory kultury francuskiej cechują się czarem, zarazem delikatnością, która jednak bez trudu przechodzi w wytworną ironię, a nawet zgryźliwość, nadto lekkością, pełnią artyzmu i nierzemieślniczej swobody².

Co istotne, właśnie wiara w nadzwyczajną wartość estetyczną kultury francuskiej stanowiła ważki czynnik jednoczący Francuzów w drugiej połowie XVIII oraz w pierwszej połowie XIX stulecia. Na niej m.in. fundowano dumę narodową, dzięki której, mimo zawirowań rewolucyjnych oraz epopei napoleońskiej, rozpad państwa francuskiego nie stał się faktem.

${ }^{1}$ Nastawienie markiza dobrze koresponduje z rozpowszechnionym wśród oświeceniowców francuskich „zhierarchizowaniem kolektywów ludzkich”, które według Zbigniewa Drozdowicza było tak skonstruowane, by ukazać „wyższość Europejczyków nad ludami innych kontynentów, dalej, wyższość narodów Europy Zachodniej nad narodami Europy Wschodniej, jeszcze dalej, wyższość Francji nad pozostałymi narodami, i w końcu wyższość oświeconej części jej społeczeństwa nad częścią nieoświeconą" (Drozdowicz, 1991, s. 78).

2 Klasycznym dziełem prezentującym scharakteryzowany sposób patrzenia na historię Francji jest Wiek Ludwika XIV Voltaire'a (1694-1778). Zgodnie z uwagami Z. Drozdowicza, w pracy tej ,mamy do czynienia z obroną takiej całości, jaką jest rozumiany na sposób oświeceniowy naród, w szczególności naród francuski. W jego historii dostrzegał Voltaire wiele cierpienia i udręki - w pewnym momencie stwierdzał nawet, że historia ta jest nagromadzeniem zbrodni, szaleństwa i nieszczęść, wśród których dostrzegamy jedynie pewne cnoty, pewne szczęśliwe okresy, podobnie jak wśród dzikiego pustkowia spotyka się rozrzucone tu i ówdzie osady. Nie był on jednak pesymistą; przeciwnie - podobnie jak wielu innych w tamtej epoce był optymistą dziejowym i wierzył w to, że w historii ludzkości ma miejsce nieustanny postęp" (Drozdowicz, 1991, s. 66). 
Trudno też się dziwić, że sukcesy estetyczne traktowano w XVIII oraz XIX-wiecznej Francji jako silne źródło legitymizacji władzy. Zwolennicy rozmaitych rozwiąań ustrojowych starali się wówczas wykazywać, że to właśnie ich propozycje wyjątkowo sprzyjają rozwojowi twórczości artystycznej. Przed rewolucją, odnotował J. Baszkiewicz, publicyści antyreżimowi często argumentowali, że brak wielkich dzieł to poważny symptom kompleksowego kryzysu monarchii absolutnej. Nadto, w świetle ich marzeń, zmiana ustroju miała poskutkować gwałtownym rozkwitem twórczości. Tymczasem, epoka rewolucyjna nie tylko nie przyniosła wysypu geniuszy, lecz w powszechnym odczuciu, zwłaszcza w sferze literatury, obfitowała w pisarstwo miałkie, bez błysku. Ten wstydliwy stan rzeczy chętnie podkreślali przeciwnicy rewolucji, w szczególności potomkowie francuskich rodów arystokratycznych (Baszkiewicz, 2009, passim). Stąd właśnie w czasach restauracji salonowym truizmem był pogląd, w świetle którego rozwiązania antyfeudalne zwiększają wprawdzie krag obywateli partycypujących w życiu politycznym, lecz jednocześnie zabijają różnorodność oraz twórczy indywidualizm. Cała trudność, w świetle powyższych uwag, polegała na tym, by stworzyć warunki, w których Francuzi chcieliby i potrafili przekuwać swą aktywność w godne podziwu pomniki kultury i sztuki. Poszukiwanie środków gwarantujących swobodę twórcza, lecz zarazem stymulujących kreatywność było jednym z głównych motywów epoki. Podejmując go, wielu wyprawiało się poza granice Francji, szukając rozwiązań niestandardowych, które można by zaadoptować na francuski grunt. $Z$ tej też właśnie przyczyny Alexis de Toucqeville (1805-1859) przepłynął Atlantyk, by przyjrzeć się demokracji amerykańskiej i zrozumieć jej istotę. Dlatego też markiz de Custine pojechał do Rosji i przez kilka miesięcy zwiedzał główne ośrodki imperium carów.

Eksploatowana przez markiza opozycja Francja-Rosja nie wyczerpywała się w przeciwstawieniu kultury starej i młodej. De Custine oparł swe wywody m.in. na przekonaniu, w świetle którego francuskość różniła się od rosyjskości wyczuciem proporcji i taktu. Innymi słowy, wyrażał opinię, że dojrzałość Francuzów była wszechstronna - poszczególne aspekty ich charakteru narodowego pasowały do siebie, tworząc obraz wprawdzie nie harmonijny, lecz w pewnym sensie spójny i przekonujący. Rosjanie natomiast - w świetle stanowiska prezentowanego w La Russie en 1839 - byli narodem skrajnie nierównym, $w$ ich charakterze przedziwnie miały mieszać się przerosty z niedowładami. Francuskość oznaczała kształt, formę, porządek, natomiast rosyjskość - bezład i poważne deformacje. Zgodnie z uwagą I. Grudzińskiej-Gross, markiz partycypował w tradycji myślenia, w świetle którego Rosja „,była i zarazem nie była azjatycka, była i zarazem nie była europejska. Arabka, choć blondynka, młoda, a już stara, ucywilizowana, lecz prymitywna, podobna do Rzymian, Chińczyków i Tatarów, a jednocześnie od nich wszystkich odmienna" (Grudzińska-Gross, 2000, s. 84).

Hybrydowość, nawet monstrualność Rosji - często przypuszczali Europejczycy w czasach de Custine'a - nie była jakoby dziełem przypadku. Rosjanie mieli być narodem przypominającym potężne dziecko-potworka, pokrakę (Grudzińska-Gross, 2000, s. 69-71). Stwór ten, nierzadko sugerowano, wiedząc o swej niewydarzoności, nie może się z nią pogodzić. Jest zarazem na tyle przebiegły i potężny, by przyjmując pozy bądź to przymilne, bądź to groźne maskować swą nieforemność. Zdaje się, iż taka postawa - zdaniem markiza, jak i wielu jego współczesnych - zasługiwała na dezaprobatę. W świetle tej optyki, przyzwoitość wymagała zatem, by rosyjskie pochlebstwa i szantaże demasko- 
wać, wypowiadając się bez ogródek w sprawie rzeczywistej kondycji kultury rosyjskiej. Tę natomiast, w myśl komentarzy de Custine'a, należy postrzegać jako wytwór dzikusów, którzy udają ludzi cywilizowanych. W tym właśnie przejawia się, jego zdaniem, rosyjska synteza Wschodu z Zachodem - jej ukryta logika sprowadza się do zasady, zgodnie z którą powierzchowna europejskość ma maskować rzeczywistą azjatyckość. Stąd natomiast, twierdził markiz, bierze się szeroki wachlarz obyczajów, którymi Rosjanie usiłują łudzić nie tylko obcych, lecz przede wszystkim siebie. To oznacza, że według niego „nie stali się jeszcze ludźmi ułożonymi, ale już są zepsutymi dzikusami” (cyt. za: Grudzińska-Gross, 2000, s. 81). Niemniej, w opinii de Custine’a, mimo usilnych starań, realiów oszukać się nie da: „Obyczaje Rosjan, mimo wszystkich pretensji tych półdzikusów, są i długo pozostaną okrutne. Stulecie zaledwie minęło od czasów, kiedy przestali być Tatarami. To Piotr Wielki pierwszy zmusił mężczyzn, by dopuścili kobiety do swoich towarzyskich spotkań. Wielu z tych cywilizacyjnych parweniuszy ukrywa pod nowoczesną elegancją skórę niedźwiedzia; wywrócono tylko skórę kudłami do wewnątrz, ale jeśli trochę poskrobać, znowu ukazuje się szczeciniaste futro" (cyt. za: Grudzińska-Gross, 2000, s. 81).

Należy podkreślić, że markiz czuł się w pełni uprawniony, by pisać o Rosji ostro, nie stroniąc od wyrazów pogardy. Co więcej, uważał, że wyświadcza w ten sposób Rosjanom przysługę. Przekonującym wydaje się pogląd, iż z jego perspektywy, wymagali oni forsownej i długotrwałej pedagogiki, która winna opierać się na karceniu i naganach. Jedynie w ten sposób, w świetle optyki markiza, można Rosjan skłonić do refleksji, jako że „ci ludzie Wschodu, tak przyzwyczajeni do wdychania najordynarniejszego kadzidła, uważający się zawsze za wiarygodnych, gdy się wychwalają nawzajem, będą wrażliwi tylko na przygany" (de Custine, 1989, s. 10-11). Swoje zapędy pedagogiczne, jak podkreśliła I. Grudzińska-Gross, de Custine motywował niezgodą na tłamszenie godności mieszkańców imperium. Inspirowany gorzkimi ocenami, które miał usłyszeć m.in. od Polaków, postrzegał Rosję jako więzienie narodów i ludów - „był jednym z tych niewielu podróżników, którzy potrafili dostrzec krzywdę na twarzy każdego przechodnia" i nie potrafił „zaakceptować bezsensowności ucisku i całkowitej bezsilności jednostki w Rosji”. Jego pisarstwo, w świetle oceny I. Grudzińskiej-Gross, wynikało z przekonania, że „Dawanie świadectwa było obowiązkiem, który dyktowało mu sumienie”. Markiz, zgodnie z jej interpretacją, „Współuczestniczył w powstawaniu nowego podówczas rodzaju pisarstwa jako dawania świadectwa brutalności i bezsensowności wojen oraz rewolucji, pisania w udręce, tak jakby przez to można było w jakimś sensie oswoić się $\mathrm{z}$ groza. Było to apokaliptyczne relacjonowanie historii, w którym pisarz bronił swych zdrowych zmysłów i protestował, odnotowując każdy odcień ludzkiego nieszczęścia. W takim momencie jego pisarstwo przestawało być romantyczną ekspresją własnego ja, stając się medium, dzięki któremu można by usłyszeć głosy prześladowanych" (Grudzińska-Gross, 2000, s. 42).

Moralny sprzeciw - twierdziła I. Grudzińska-Gross - w opinii markiza, a także wielu jego naśladowców, uzasadniał postawę, w myśl której o Rosji można i trzeba pisać krytycznie. Jej zdaniem, wielka zasługa autora La Russie en 1839 polega właśnie na wynalezieniu nowego typu pisarstwa - literatury rozliczeniowej, pisanej przez świadka w imię sprawiedliwości, ku chwale i pamięci ofiar opresyjnych reżimów.

Należy zarazem zwrócić uwage, że I. Grudzińskiej-Gross nie stropił zanadto fakt, iż markiz dość niefrasobliwie pisał o kulturze, którą znał beznadziejnie powierzchow- 
nie. Interpretatorce nie wydała się również zbyt kontrowersyjną swoista deklaracja braku rzetelności, którą markiz złożył w „Przedmowie” swoich listów. Tymczasem - nad czym I. Grudzińska-Gross przeszła pomimo - można znaleźć tam budzące co najmniej konsternację wyznanie: „Każdy uczciwy Rosjanin zgodzi się z tym, że jeśli popełniłem jakieś pomyłki w szczegółach z braku czasu, by sprostować moje złudzenia, w sumie odmalowałem Rosję taką jaką jest. Wezmą pod uwagę trudności, które miałem do pokonania i pogratulują mi sukcesu oraz szybkości, z jakimi udało mi się uchwycić cechy ich pierwotnego charakteru pod polityczną maską, zniekształcającą go od tylu stuleci..." (de Custine, 1989, s. 11).

Możliwe, że taka postawa wydawała się markizowi tym bardziej właściwa, iż autopercepcji Rosjan nie postrzegał tylko i wyłącznie jako problemu wewnątrzrosyjskiego. Imaginacja rosyjska, w mniemaniu de Custine’a, mogła być źródłem istotnych zagrożeń dla całej Europy. Rosjanie, uważał, zawarli swoisty pakt z władza, którego istotą była zgoda na teraźniejsze upodlenie, w zamian za obietnicę przyszłej dominacji nad narodami europejskimi. W myśl konstatacji markiza, „Ten naród, z gruntu agresywny, o chciwości pobudzonej przez ubóstwo, odpokutowuje z góry, w upokarzającym poddaniu, plan narzucenia tyranii innym narodom: chwała i bogactwa, jakich się spodziewa, niosą mu pociechę pośród hańby, w jakiej żyje" (cyt. za: Grudzińska-Gross, 2000, s. 43). Zatem, mniemał de Custine, kwestia uświadomienia Rosjan jest kwestią być albo nie być dla narodów europejskich. W konsekwencji, jego zdaniem, za wszelką cenę należało zachęcać ich, by przestali się samooszukiwać i uznawszy mizerię swego położenia, zaczęli żmudnie uczyć się od Zachodu i dojrzewać. W przeciwnym wypadku, w świetle odczuć i kalkulacji de Custina, niebezpieczeństwo konfrontacji rosyjsko-europejskiej musiałoby stale narastać, coraz realniej grożąc wybuchem nowej wielkiej wojny (Grudzińska-Gross, 2000, s. 43-44).

Sumując, wypada stwierdzić, że racje, dla których de Custine spisał La Russie en 1839, dalece nie sprzyjały tworzeniu pracy zdystansowanej, przepełnionej troską o uchwycenie złożoności kultury rosyjskiej. Markiz de facto nie wykroczył poza zaklęty krag stereotypów, rozbudowując go znacząco i znajdując nośne frazy, które łatwo zapadały i nadal zapadają w pamięć. Z czasem jego praca stała się wzorcem, w oparciu o który kolejne pokolenia usiłowały interpretować rosyjską skrytość. A zatem „Listy z Rosji" nie tylko świadczą o kunszcie literackim autora. W nich zenitu sięga nieporadność, z jaką wielu ludzi Zachodu usiłowało i nadal usiłuje zrozumieć, czym jest Rosja. Markiz, jak zauważyła I. Grudzińska-Gross, ,pisał historię Rosji po to, by wykluczyć ją z Europy" (Grudzińska-Gross, 2000, s. 64). Stworzył dzieło na tyle sugestywne, że weszło do szerokiego obiegu kulturowego i nadal funkcjonuje w nim jako praca, która rzekomo mówi o Rosjanach wyjątkowo wiele.

Mit Rosji nieobliczalnej, dzikiej, podstępnej i wrogiej szczególnie skwapliwie kultywowali i kultywują przedstawiciele narodów, które bywały przez Rosjan podbijane lub uzależniane. Wśród Polaków nie zawsze opierał mu się i chyba nie chciał się opierać m.in. Czesław Miłosz (1911-2004), który wspominał, że wykładając w Stanach Zjednoczonych, chętnie posługiwał się wyimkami z de Custine'a. Przyznawał, że nie czytał ich ze studentami na chłodno, deklarując: „Nie ma sensu udawać, że jest się wyjątkiem, i ukrywać obsesję, właściwą wszystkim Polakom. Przeciwnie, trzeba się do niej przyznać i starać się ją badać w sobie samym możliwie beznamiętnie. Polacy i Rosjanie nie lubią albo, ściślej, 
mają dla siebie wszelkie nieprzychylne uczucia, od pogardy, odrazy do nienawiści, co nie wyklucza niejasnego wzajemnego pociagu, ale zawsze naznaczonego nieufnością" (Miłosz, 2010, s. 19; rozwinięcie tego wątku w antologii de Lazari, 2004).

Eseistyka Cz. Miłosza dotycząca rosyjskości miała być i jest prowokacyjna. Niewątpliwie, interpretując ja, wypada brać pod uwagę fakt, że autor celowo mógł wyolbrzymiać i pewnie wyolbrzymiał wiele swoich sądów. Niemniej trudno pozbyć się wrażenia, że niejednoznaczna forma posłużyła, by raz jeszcze, z dość żywym przekonaniem, powtórzyć niejedną opinię znaną z La Russie en $1839^{3}$. I tak, co prawda niekategorycznie, jednak dobitnie Cz. Miłosz powracał do idei, w myśl której Rosjanie, o ile chcieliby się rzeczywiście czegoś o sobie dowiedzieć, powinni zwrócić uwagę na to, co mówią ludzie z zewnątrz. Niemniej pogląd de Custine'a uległ tu pewnej transformacji, tzn. w opinii Cz. Miłosza to nie Francuzi, a narody z Rosjanami sąsiadujące potrafiłyby najtrafniej ocenić tych ostatnich. Nadto, w esejach zawiera się pogląd, w myśl którego niewykluczone, że nie tylko Rosjanie, lecz każdy naród to niepowtarzalna, jedyna w swoim rodzaju, obyczajowa maszkara: „Być może wszystkie narody, zobaczone jako całość, a nie jako zespół jednostek, są odrażające i sąsiedzi na ich przykładzie odkrywają tylko niemiłą prawdę o społeczeństwach ludzkich w ogóle. Nie jest wykluczone, że Polacy wiedzą o Rosjanach to, co Rosjanie wiedzą o sobie samych, nie chcąc się do tego przyznać, i odwrotnie. Stąd w niechęci do Polaków u Dostojewskiego nacjonalisty, kryje się jakby gest obronny" (Miłosz, 2010, s. 19).

${ }^{3}$ Strategię narracyjną Cz. Miłosza obrazuje fragment, w którym autor mówi jako świadek egzekucji niemieckiego jeńca, przeprowadzonej przez żołnierzy radzieckich w styczniu 1945 r. Rosjanie, z którymi wówczas się zetknął, byli dla niego ,prawowitymi dziedzicami tych samych darów, z jakich czerpali Dostojewski i Tołstoj. I jak ich przodkowie pobili Napoleona, oni pobili Hitlera”. Patrzyli „ku środkowi izby, gdzie stał mężczyzna mogący mieć nieco poniżej trzydziestki, w długim białym kożuchu, o ładnej twarzy typu spotykanego w Nadrenii. Jeniec niemiecki; konkwistador, teraz w ich mocy”. Zgodnie z Miłoszowym wspomnieniem, Rosjanie nie nienawidzili Niemca, lecz w swoisty sposób współczuli mu: „Ponieważ bał się, jak złapane w klatkę zwierzę, nieznanego, jeden z nich wstał i dał mu papierosa, ten ruch ręki oznaczał pojednanie. Inny podszedł i poklepał go po plecach. Potem zbliżył się do niego oficer i powoli, dobitnie, wygłosił do niego długie przemówienie. Było to bezużyteczne, bo Niemiec nic nie rozumiał, ale przylepiał oczy do ust mówiącego: pies, który stara się odgadnąć treść słów swego pana. I jednak z przyjaznego tonu wywnioskował, że nie chcą się mścić, nie chcą wyrządzać mu krzywdy. Niech się nie boi - powtarzał z naciskiem podoficer. Nic złego mu się nie stanie, wojna dla niego już skończona, nie jest już wrogiem, ale zwykłym człowiekiem, będzie pracować dla pokoju i zaraz zostanie odprowadzony na tyły. Litość, a nawet serdeczność w głosie, łagodna powaga autorytetu uspokajały jeńca i nieśmiało uśmiechnął się; wdzięczność. Kiedy jeden z żołnierzy zebrał się sennie ze swojej ławy, choć nie padł żaden rozkaz, i wziął go z izby, powrócili w poprzednią apatię, odpoczynek ludzi fizycznie strudzonych. Po upływie paru minut konwojent wrócił, wlokąc za sobą biały kożuch, rzucił go obok swego worka, siadł i skręcał papierosa. We wciagganiu dymu, w pluciu na podłogę zawarta była ich melancholijna refleksja o kruchości życia ludzkiego: ot los". Co najistotniejsze, zdaniem Miłosza, okrucieństwo przedstawionych w scenie Rosjan wynikało z fatalizmu posuniętego do makabrycznych granic: ,nie zabili go z nienawiści, ale z szacunku dla konieczności. Ta konieczność przybierała postać kłopotu z przekazaniem jednego jeńca na tyły albo postać białego kożucha. Być może w ich ocenie zabierać człowiekowi okrycie i tak wypuszczać go na mróz byłoby uczynkiem brzydkim i niegodnym. Bo my sami rozpoznajemy, co jest koniecznością, zakreślamy granice pomiędzy konieczne i możliwe. Odegraną przez nich komedię humanitarną ktoś mógłby nazwać podstępem, gdyby nie odpowiadała najwyraźniej ich wewnętrznej potrzebie. Ze szczerym przeżyciem szło zresztą w parze przekonanie, że taką operację należy przeprowadzić możliwie najłagodniej i najciszej” (Miłosz, 2010, s. 29-31). 
W tekście Cz. Miłosza, podobnie jak w listach de Custine’a, nie brak uwag, w myśl których Rosjanie przez długie stulecia zmuszeni byli odgrywać rolę uczniów. Jednymi z istotnych ich nauczycieli mieliby być - twierdził Cz. Miłosz - Polacy, którzy w stosunku do swego wschodniego sąsiada wielokrotnie i z sukcesami odgrywali rolę krzewicieli standardów. Przez stulecia, wskazywał, Rosja czerpała od Polski wzorce kulturowo-cywilizacyjne - o czym dobrze pamiętaja, choć nie zawsze chcą wspominać obie nacje. Jednak wraz z upływem stuleci państwo polskie stawało się coraz słabsze, a rosyjskie - silniejsze. W rezultacie wykształciła się i ugruntowała relacja typu „miękki nauczyciel-twardy uczeń”, skutkująca obustronnymi kompleksami i postawami nieskrywanej i nierzadko skrajnej niechęci. W sposób myślenia i bycia Polaków wobec Rosjan - pisał Cz. Miłosz - „zawsze wkradał się odcień pogardy zabarwiony litością"4. Ze względu na taką postawę, Rosjanie nie tylko czuli głęboką urazę, lecz w rewanżu wykreowali radykalnie nieprzychylny wizerunek Polaka i polskości. Zgodnie z opisem Cz. Miłosza, „Dla Rosjan polski konwencjonalny obyczaj dygów, uśmiechów, grzeczności i pochlebstw był pustą formą, a tym samym fałszem. Ładowali w siebie przekonanie, że są wyżsi od powierzchownych, płytkich i motylkowatych, $\mathrm{z}$ ich drażliwym honorem i skłonnością do wypalania się w heroicznych a bezsensownych porywach. Dość przenikliwi, żeby rozróżnić starszą kulturalną formację, bolejący nad swoją niższością wobec wszystkiego co zachodnie, z nieczystym sumieniem sług autokracji, zdawali sobie sprawę, czemu w powietrzu unosi się niewymówione słowo: barbarzyńcy" (Miłosz, 2010, s. 23).

Na tym tle, w mniemaniu Cz. Miłosza, nietrudno pojąć, dlaczego Rosjanie z wielką niechęcia, a czasem z agresją reagowali na jakąkolwiek polską krytykę kierowaną pod adresem rosyjskiej kultury. Nieważna była tutaj kwestia trafności lub nietrafności uwag, istotnym był fakt, że Polaków uznawano za uprzedzonych. W odczuciu wielu Rosjan, przegrany, lecz wyniosły Polak źle mówił o Rosji, by leczyć swe frustracje. Był dla nich uzurpatorem, który ocenia, choć nikt go o ocenę nie prosi. Dlatego właśnie, z oburzeniem odnosili się do mickiewiczowskiej krytyki caratu - i to mimo że jego spostrzeżenia „nie różnią się w istocie od treści satyr Gogola” (Miłosz, 2010, s. 22).

Wypada pamiętać, że Adam Mickiewicz (1798-1855), w oczach Rosjan, to oczywiście przedstawiciel narodu podbitego, lecz przede wszystkim obcy, a więc „człowiek, którego krytyki nie łagodzi przywiązanie" (Miłosz, 2010, s. 21). Z tego względu, jego obecność budzi doznania i pragnienia ambiwalentne, nadzieje zmieszane z podejrzeniami, fascynację połączoną z wrogością. Z jednej strony, jako ktoś z zewnątrz miał szansę zaobserwować coś istotnego, co dotychczas uchodziło uwadze. $Z$ drugiej, sam się upoważnił do wypowiadania sądów tym radykalniejszych, im mniej sprawdzonych. Jego wypowiedzi Rosjanie niejednokrotnie odbierali nie tyle jako niejednoznaczne, co właściwie jako bezczelne, a może nawet nienawistne. Manifestując sympatię wobec Rosjan, nierzadko uważali, oczerniał ich instytucje polityczno-społeczne - nieproszony kreował się na moralnego obrońcę ludu rosyjskiego, który, w świetle jego przekonań, elity rosyjskie traktowały jak przedmiot eksploatacji (Miłosz, 2010, s. 22).

${ }^{4}$ Polacy, pisał Cz. Miłosz: „Czuli się wyżsi przez swoją tradycję, swój katolicki kodeks moralny, swoją przynależność do Zachodu. Policzkował ich jednak jakiś ołowiany spokój na dnie charakteru Rosjan, ich cierpliwość, niewzruszoność, skrajność w ideałach, niedostępna dla ludzi myślowego kompromisu, i dlatego upokarzała pamięć klęski” (Miłosz, 2010, s. 23). 
Zaznaczyć wypada, że w XIX-wiecznej Rosji motyw jej nieokreśloności nie tylko irytował, lecz również inspirował. W nawiązaniu do europejskich, w tym polskich charakterystyk rosyjskiego nieokrzesania, niejeden autor realizował strategię paradoksalnego wynoszenia Rosji ponad Zachód. Za klasyka operującego tym sposobem szkicowania rzeczywistości uchodzi Piotr Jakowlewicz Czaadajew (1794-1856) - notabene znany markizowi de Custine i silnie oddziałujący na jego wyobraźnię, zarówno poprzez twórczość, jak i biografię (Grudzińska-Gross, 2000, s. 119-120).

Przyjętą przez P. Czaadajewa waloryzację kultur wykorzystywano i rozwijano przez cały XIX, a także $\mathrm{w}$ XX w. W świetle omawianych mniemań, mieszczących się w ramach tzw. rosyjskiego misjonizmu, zapóźnienie cywilizacyjne Rosji to atut - dzięki niemu chroni ona moce, które są gwarantem nie tylko jej kulturowej wyjątkowości, lecz również stanowią nadzieję dla innych narodów ${ }^{6}$. Świat - twierdzili zwolennicy różnorakich koncepcji misjonistycznych - olśniony rosyjską kulturą, może, powinien i będzie w przyszłości lepszy. Rosja - w myśl ich poglądów - ma bez wątpienia do spełnienia misję, a dowodzą tego, jakoby bezsprzecznie, jej zapóźnienie, arytmia rozwojowa, skrajności i kontrasty, zadziwiające przemieszanie radykalnego zła $\mathrm{z}$ radykalnym dobrem.

Koncepcję P. Czaadajewa ${ }^{7}$ - przytaczaną niezliczoną ilość razy przez niezliczoną rzeszę autorów - zrazu interpretowano jako atak na rosyjskość. Swoje poglądy zawarł w Listach filozoficznych, pisanych po francusku w latach 1829-1831. Szczególnie głośny stał się „List pierwszy”, zawierający opinię, w myśl której Rosja przez wieki funkcjonowała jakby poza czasem, poza marginesem dziejów powszechnych (P. Czaadajew twierdził: „Patrząc na nas można by powiedzieć, że ogólne prawo ludzkości nas nie dotyczy. Samotni w świecie, nic nie daliśmy światu, niczego nie nauczyliśmy go; nie wnieśliśmy

${ }^{5}$ Markiz w pierwszym wydaniu La Russie en 1839 zamieścił portret P. Czaadajewa i uczynił go jedną z najważniejszych postaci w swojej relacji (zob. Walicki, 2002, s. 74).

${ }^{6} \mathrm{~W}$ badaniach nad myślą rosyjską zabiegano, aby nie mylić misjonizmu z mesjanizmem. Zdaniem Andrzeja de Lazariego (ur. 1946), „Gdy Rosjanie mówią o misji narodu rosyjskiego jako bogonoścy, mamy do czynienia z mesjanizmem; gdy mówią o misji narodu rosyjskiego, sowieckiego lub euroazjatyckiego, niekoniecznie utożsamiając się z misją prawosławia - z misjonizmem" (de Lazari, 1995, s. 51-52). Podobnie kwestię ujęła Iwona Massaka, która w ślad za A. Walickim, zaznaczała, że pojęcie „misjonizmu” jest szersze aniżeli „mesjanizmu”, a każdy „mesjanizm” jest szczególnie zabarwionym „misjonizmem” (Massaka, 2001, s. 14-15; Walicki, 1970, s. 288). Natomiast według M. Bierdiajewa, „W mesjanizmie rosyjskim, tak właściwym narodowi rosyjskiemu, czysta mesjanistyczna idea Królestwa Bożego, królestwa prawdy, przesłonięta była ideą imperialistyczną, wolą mocy. Widzieliśmy to już w ideologii Moskwy jako Trzeciego Rzymu. Również w komunizmie rosyjskim, który przejął rosyjską ideę mesjanistyczną w areligijnej i antyreligijnej formie, dokonało się to samo skażenie poszukiwania królestwa prawdy wolą mocy" (zob. Bierdiajew, 1999, s. 205-206; nt. koncepcji Moskwy Trzeciego Rzymu zob. np. Andrusiewicz, 1994, s. 67-92; de Lazari, 1996, s. 9 i n.).

7 Życie i twórczość P. Czaadajewa poddawano i poddaje się rozległym, i niekiedy bardzo szczegółowym badaniom. Obszerny spis rosyjskiej literatury przedmiotu znajdujemy w Bibliotece Maksyma Moszkowa; zob. też Сапов, 1991. Spośród prac rosyjskich wypada wyróżnić pracę Гершензон, 1908 oraz zbiór tekstów o P. Czaadajewie: Чернецов, 1998. Wśród prac anglosaskich: McNally, 1971; zbiór prac P. Czaadajewa: Czaadajew, 1991. Wśród prac polskojęzycznych na uwagę zasługują: Bezwiński, 1980; idem, 1983; Chojnicka, 1983; Dobieszewski, 1986; idem, 1986; Mucha, 1995; Walicki, 2002, s. 59-85. Polski przekład Listów filozoficznych, Czaadajew, 1992; francuska wersja pierwszego z „Listów filozoficznych”: Première. ,Listy o filozofii historii” w wersji rosyjskiej zob. Czaadajew, Философические письма. 
żadnej idei do masy idei ludzkich, niczym nie przyczyniliśmy się do postępu ludzkiego rozumu, a to, co dał nam ten postęp, wypaczyliśmy") (Czaadajew, 1961, s. 106) ${ }^{8}$.

Należy zauważyć, w ślad za Orlando Figesem (ur. 1959), że przytoczone mniemanie nie było aż tak oryginalne, jak się na ogół twierdzi (Figes, 2002, s. 99-100). Opinia P. Czaadajewa bardzo dobrze wpisywała się w ogólny klimat ideowy epoki. Rządził Mikołaj I, który zdławiwszy w pierwszych dniach swego panowania powstanie dekabrystów, usilnie zabiegał, by społeczeństwo pozostawało pod możliwie kompleksową obserwacją tajnych służb. Nadto, biurokracja mikołajowska starała się ograniczać inicjatywy społeczne - od poddanych car i jego urzędnicy oczekiwali przede wszystkim bierności. Stan ten jaskrawo kontrastował z nadziejami pokolenia, którego przedstawiciele w 1812 roku stanęli w obronie ojczyzny, wierząc zarazem głęboko, że po odparciu Napoleona carat wprowadzi ambitne reformy. Skoro tak się nie stało, ludzie ci przeżyli głębokie rozczarowanie, czemu przez lata dawali wyraz w salonowych dyskusjach. Wielu z nich, w tym również P. Czaadajew, twierdziło, że Rosja pozostaje krajem zacofanym, wymagającym radykalnych zmian. Nawiązywali chętnie do niemieckiej oraz francuskiej myśli społeczno-politycznej, szukając w niej natchnienia i podpowiedzi dla swojego kraju.

Wystąpienie P. Czaadajewa zapamiętano wyjątkowo z kilku względów9. Po pierwsze, P. Czaadajew świetnie nadawał się na romantycznego bohatera (heroiczna wojskowa przeszłość, barwne, salonowe życie w Moskwie, postawa silnie melancholijna, skłonność do mistycyzmu). Po drugie, jego ocena kondycji rosyjskiej jawiła się jako ekstremalna, lecz przy tym wyjątkowo wyrafinowana intelektualnie. Stąd szybko rozpowszechnił się pogląd, w myśl którego P. Czaadajew chciał przede wszystkim obrazić Rosję i Rosjan, a istota jego „Listu” zamyka się w lekceważącej konstatacji „Być Rosjaninem to być nikim"”10. Po trzecie, ganiąc Rosję, ostentacyjnie wychwalał Europę, a także z zapałem pisał o walorach katolicyzmu oraz mankamentach prawosławia. Po czwarte, należał do

${ }^{8} \mathrm{~W}$ innym fragmencie pisał: „myśmy nigdy nie szli ramię przy ramieniu z innymi narodami; nie należymy do żadnej z wielkich wspólnot rodu ludzkiego; nie należymy ani do Zachodu, ani do Wschodu i nie posiadamy tradycji ani jednego, ani drugiego. Umieszczonych jak gdyby poza czasem nie objęła nas powszechna edukacja ludzkości” (Walicki, 1961, s. 96). W 1836 r. „List pierwszy” opublikowano w „Teleskopie”, co niemal powszechnie uznano za skandal - wiele osób bojkotowało P. Czaadajewa. Następnie poddano go dozorowi lekarskiemu, uznając za obłąkanego. W zakładzie dla psychicznie chorych umieszczono również Jekaterinę Panową, adresatkę listu. Redaktor „Teleskopu”, Mikołaj Nadieżdin został zesłany do Ust-Sysolska. A. Bołdyriew - cenzor, który zezwolił na druk, stracił piastowane przez niego stanowiska. Historia głęboko zapadała Rosjanom w pamięć. Zgodnie z opinią Osipa Mandelsztama, przytoczoną przez Piotra Mitznera, „Ślad pozostawiony przez Czaadajewa w świadomości społeczeństwa rosyjskiego - jest głęboki i niezatarty, jak wycięty diament we szkle" (Cyt. za: Mitzner, 2012, s. 190; zob. też idem, 2012, s. 189-192; Walicki, 1961, s. 91 oraz Nikitienko, 1998, s. 83).

9 Zgodnie z egzaltowanymi, lecz bardzo popularnymi słowami A. Hercena, uznano je za ,wystrzał, który rozległ się wśród ciemnej nocy”, sprawiając, że ,trzeba było się obudzič” (Hercen, 1966, s. 263).

${ }_{10}$ Wątek ten podjęła m.in. komisja śledcza badająca sprawę druku „Listu” w „Teleskopie”, w skład której weszli A. Benkendorff, szef korpusu żandarmów, naczelnik III Oddziału, S. Uwarow, minister oświecenia narodowego, hr. N. Protasow, oberprokurator Św. Synodu, A. Mordwinow, naczelnik kancelarii III Oddziału. W mniemaniu komisji, szczególnie oburzającym był fakt, że P. Czaadajew opublikował tekst, „w czasie, gdy rząd dokłada wszelkich starań, by ożywić ducha narodowego, wywyższyć wszystko, co ojczyste”. Stwierdzono również, iż autor „Listu”, skoro nie mógł wyzbyć się nienawistnego spojrzenia, „, najgorszym wypadku powinien milczeć, by nie kusić niedoświadczonych i nierozgarniętych” (Доклад, 1998, s. 112-113 і 767). 
pokolenia dekabrystów, a zatem z punktu widzenia caratu, jego mniemania wymagały szczególnej kontroli. Po piąte, nie ograniczył się do krytyki salonowej, lecz zdecydował się na jej druk. Po szóste, trafił na liberalnego cenzora, który nie przeciwstawił się publikacji i nie złagodził jej ciętości. Po siódme, uznając go za psychicznie chorego, władze odpowiedziały na jego postępek w sposób szczególnie przemawiający do wyobraźni ceniących wolność wypowiedzi inteligentów (w świetle ich narracji, człowieka, który odważył się mówić, co myśli, carat potraktował jak wariata). Po ósme, poglądy P. Czaadajewa znalazły poważnych ideowych przeciwników, którzy w odpowiedzi na „List” opracowali i zaczęli upowszechniać twórczość słowianofilską, jedno z najpoważniejszych źródeł rosyjskiej myśli politycznej.

Już na początku lat trzydziestych XIX w., a więc na długo przed skandalem z publikacją „Listu pierwszego”, stanowisko P. Czaadajewa surowej krytyce poddał Iwan Wasiliewicz Kiriejewski (1806-1856) ${ }^{11}$. W jego mniemaniu, postawa autora Listów filozoficznych nie była zjawiskiem niezwykłym, lecz spotykanym w Rosji od czasów Piotra I. Car ten, żywiąc pogardę wobec rodzimej kultury, usiłował radykalnie zeuropeizować Rosjan. W rezultacie tych zabiegów wykształciła się swoista grupa ludzi, którzy będąc Rosjanami nienawidzili wszystkiego, co rosyjskie i jednocześnie bałwochwalczo cenili Zachód. Ludzie ci, uważał I. Kiriejewski, przez 150 lat pluli na swoją ojczyznę i nie ustawali w wysiłkach, by zohydzić Rosjanom ich tradycje. W konsekwencji, twierdził, uczciwość i miłość do własnego kraju wymagały, by dać im odpór i z zapałem kultywować rodzimość, odwołując się do folkloru oraz historii ${ }^{12}$.

Zdaje się jednak, że ta krytyka nie była lub przynajmniej mogła nie być trafiona. Poglądy P. Czaadajewa były niejednoznaczne - w ich świetle, rosyjskie zacofanie jawiło się jako zjawisko ambiwalentne, niosące zarówno zagrożenia, jak i szanse. Co najistotniejsze, w „Liście pierwszym”, P. Czaadajew nie przesądzał, jaka będzie przyszłość Rosjan, a także nie określał ich mianem narodu przeklętego, który skazany miałby być, by wiecznie kultywować swą cywilizacyjno-kulturową niedojrzałość. Zakładał nawet, że tak długie trwanie Rosji na marginesie dziejów powszechnych nie może być przypadkiem, lecz z pewnością wiąże się z jakimś szczególnym zamiarem Opatrzności: „I w ogóle istnieliśmy i nadal istniejemy tylko po to, aby posłużyć za jaką̧ś ważną lekcję odległym pokoleniom, które potrafią ją zrozumieć"13.

Wątki prowidencjalistyczne - w „Liście pierwszym” naszkicowane zaledwie - stały się wiodącymi w Apologii obłakanego, napisanej przez P. Czaadajewa na przełomie

${ }^{11}$ Pierwotnie P. Czaadajew pisał „Listy” z intencją by krążyły w wąskiej rzeczywistości salonowej, jako odpisy. W świetle korespondencji przedstawionej przez W. Czerniecowa, oprócz I. Kiriejewskiego przed drukiem „Listu pierwszego” stanowisko P. Czaadajewa komentowali m.in. M. Mudrow, A. Puszkin, A. Turgieniew, P. Kiriejewski (zob. Чернецов, 1998, s. 67-71).

12 Ocenę P. Czaadajewa P. Kiriejewski zawarł m.in. w liście do M. Jazykowa z 17 lipca 1833 r.: „Ta przeklęta czaadajewszczyzna w swym bezmyślnym samoupokorzeniu przeklina nad mogiłami ojców i stara się wytrzebić wszystkie wielkie wspomnienia. Czyni to, by postawić na ich miejsce swoją jednominutową przemądrzałość, która właśnie dowiodła swej absurdalności w wariackiej głowie Cz[aadajewa]" (Kiriejewski, 1998, s. 71).

${ }^{13} \mathrm{~W}$ opinii G. Przebindy, zachodziła istotna różnica między tonem prywatnych oraz salonowych wypowiedzi P. Czaadajewa. Pierwsze, jeszcze przed publikacją w „Teleskopie” były delikatniejsze, zabarwione optymizmem, nadzieją, że Rosja będzie ratunkiem dla Europy (Przebinda, 1997, s. 102-111; idem, 2003, s. 15-40; idem, 1998, s. 84 i n.; Walicki, 2005, s. 140-147). 
1836 i 1837 i pomyślanej jako odpowiedź na pełną oburzenia reakcję społeczną. W tym tekście autor twierdził wprost, iż zacofanie Rosji jest jej atutem. W jego mniemaniu, nie uczestnicząc dotychczas w głównym nurcie dziejów, Rosjanie zachowują możność mądrego stworzenia i ukształtowania własnej historii, co oznacza ich przewagę w stosunku do zgrzybiałych nacji Zachodu. Zapóźnienie, uważał, stawia Rosję w sytuacji uprzywilejowanej - może uczyć się na cudzych błędach i unikając ich sposobić się, by odcisnąć na losach świata niezatarte i godne najwyższych pochwał piętno ${ }^{14}$.

Bycie poza historia, brak historii P. Czaadajew rozumiał w sposób swoisty, oceniając zjawiska „z filozoficznego punktu widzenia”. Oczywiście chodziło mu nie o to, by twierdzić, że Rosjanie przez stulecia nie uczestniczyli w biegu zdarzeń. Starał się natomiast podkreślić, że naród rosyjski nie odniósł znaczących sukcesów, tj. nie odkrył i nie wdrożył w życie żadnego pomysłu, który mogłyby i powinny zapożyczyć od niego inne narody. W opinii P. Czaadajewa, mimo natłoku faktów, które zachodziły na ziemi rosyjskiej, Rosjanie nie wypracowali „bogatej i płodnej historii, żywych tradycji i głęboko ugruntowanych instytucji”. Wynikać to miało z rosyjskiej bezideowości - rodzima kultura, twierdził P. Czaadajew, nigdy nie rozwijała się w sposób celowy i konsekwentny, toteż zawsze brakowało porządkującego ją zestawu reguł. Była kulturą przypadku, kreowaną przez naród, „którego przeszłość nie wskazywała wyraźnie drogi, po której powinien dalej kroczyć, którego tradycje nie były w stanie stworzyć jego przyszłości, którego wspomnienia odważny prawodawca mógł bezkarnie zanegować" (Czaadajew, Apologia).

P. Czaadajew uważał, że Rosjanom brakuje formy, ponieważ niemal zawsze żyli na sposób wschodni. Oznaczało to, że hołdowali zasadzie, w myśl której umysł ludzki powinien kształtować się w procesie „koncentrowania się, pogłębiania, zamykania się w sobie". Niemniej wschodni sposób życia, w opinii P. Czaadajewa, nie mógł być uznany za naturalny dla krajów północnych, w tym dla Rosji. Wprawdzie naród rosyjski wiele zawdzięczał myśli wschodniej, niemniej nieodwołalnie musiał traktować ją i traktował jako źródło zapożyczeń. Nadto, twierdził P. Czaadajew, czas Wschodu dobiegał

${ }^{14} \mathrm{Na}$ język polski cały tekst Apologii obłakanego przetłumaczył Janusz Dobieszewski, http:// historia.upjp2.edu.pl/pro_instytut/zasoby/files/apologia_oblakanego_czaadajew.pdf. W świetle zestawionych przez niego informacji: po raz pierwszy opublikowano tę pracę dopiero w 1862 r. (w: Oeuvres choisies de Pierre Tschaadaief, publies pour la premiere fois par le P. Gagarin de la compagnie de Jesus, Paris-Leipzig, 1862). W języku rosyjskim Apologia po raz pierwszy ukazała się w: П. Чаадаев, Апология сумасшедшего, пер. С. Юрьева и Б. Денике, под ред. Вл. Ивановского, Казань 1906. Badacze na ogół traktują Apologie z pewnym dystansem. Trudno zwłaszcza rozstrzygnać, jak silnie P. Czaadajew obstawał przy poglądach przedstawionych w tym tekście. Apologia powstała po skandalu z publikacją „Pierwszego listu”, w związku z czym nie można odrzucić hipotezy, zgodnie z którą autor napisał ją, by chronić się przed szykanami. Ku potraktowaniu Apologii jako tekstu koniunkturalnego do pewnego stopnia skłaniał się I. Berlin. W eseju Rosja i rok 1848 przypomniał bojaźliwą reakcję P. Czaadajewa, który dowiedział się, że A. Hercen wspomniał o nim z uznaniem w emigracyjnej pracy O rozwoju idei rewolucyjnych $w$ Rosji. Zgodnie z relacją I. Berlina, P. Czaadajew - dowiedziawszy się o tekście - napisał list do szefa policji politycznej, w którym dystansował się od A. Hercena i deklarował swą lojalność wobec caratu. Jednocześnie - pytany o ten postępek przez bratanka - odpowiedział: „trzeba ratować własną skórę”. W opinii I. Berlina, „Ten jawnie cyniczny akt samoponiżenia ze strony najbardziej w owym czasie dumnego i miłującego wolność człowieka w Rosji jest tragicznym świadectwem wpływu przedłużających się represji na tych przedstawicieli starszego pokolenia arystokratycznych buntowników, którzy jakimś cudem uniknęli Syberii lub szubienicy” (Berlin, 2003, s. 15). 
końca, a dalsze dzieje winny postępować według wzorców zachodnich. Przede wszystkim zmiana ta wiązała się z poszanowaniem założenia, w perspektywie którego rozwój mentalny ludzkości polegać miał na „wychodzeniu ku zewnętrzu, wszechstronnym badaniu, walce $\mathrm{z}$ wszelkimi ograniczeniami" ${ }^{\prime 15}$.

Na przełomie XVII i XVIII wieku - w świetle rozumowania przedstawionego w Apologii - Rosja znalazła się na rozdrożu. Piotr Wielki, w mniemaniu P. Czaadajewa, zrozumiał, że jej położenie jest błogosławieństwem, gdyż pozwala swobodnie wybierać kierunki rozwoju. W konsekwencji uznał, że Rosjanie mogą swobodnie odwrócić się od Orientu i zwrócić ku Erebowi. Dzięki reformom Piotra I, uznawał P. Czaadajew, Rosja przestała również patrzyć w przeszłość i zaczęła spoglądać w przyszłość. W ten sposób dokonał się jakoby zwrot od czasów biernych, ku czasom aktywnym.

Niemniej ojczyzna Piotra Wielkiego nie powinna stać się drugim Zachodem. Rosjanie, uważał P. Czaadajew, mieli przejąć zachodnie wzorce, lecz wykorzystać je jako środki, służące do realizacji autonomicznych celów. W jego mniemaniu, dzięki niezwykle korzystnemu splotowi zdarzeń, młoda, pełna wigoru Rosja, nieskrępowana swą przeszłością zyskała swobodny dostęp do okupionego długotrwałymi i wyczerpującymi konfliktami, lecz jakże pouczającego doświadczenia starych, pokaleczonych i zgrzybiałych nacji zachodnich. Według P. Czaadajewa, sytuacja była tak ewidentnie komfortowa, że nie mogła być kwestią przypadku: „Sądzę, że przyszliśmy po innych po to, aby działać lepiej od nich, aby nie powtarzać ich błędów, pomyłek i przesądów. Głęboko myliłby się, moim zdaniem, co do przeznaczonej nam roli ktoś, kto chciałby twierdzić, że musimy powtórzyć cały długi szereg niedorzeczności popełnionych przez narody, które znajdowały się w mniej pomyślnej sytuacji niż my, że trzeba nam będzie przejść przez wszystkie ich nieszczęścia. Uważam naszą sytuację za szczęśliwą, o ile tylko zdołamy właściwie ją ocenić; myślę, że wielkim przywilejem jest możliwość obserwowania i osądzania świata z wysokości myśli wolnej od niepohamowanych namiętności i nędznej interesowności, które gdzie indziej mącą wzrok człowieka i wypaczaja jego sądy. Co więcej, jestem głęboko przekonany, że powołani jesteśmy do rozwiązania większości problemów porządku społecznego, urzeczywistnienia większości idei zrodzonych w starych społeczeństwach, udzielenia odpowiedzi na najważniejsze pytania nurtujące ludzkość. Często to mówiłem i chętnie powtarzam: z samej, by tak rzec, natury rzeczy przeznaczone jest nam stać się

15 Zgodnie z interpretacją proponowaną przez P. Czaadajewa, „Na Wschodzie myśl - zagłębiając się w siebie, dążąc do spokoju, kryjąc się na pustyni - pozostawiła dysponowanie wszelkimi dobrami ziemskimi władzy społecznej. Na Zachodzie idea - podążając we wszystkich kierunkach, sprzyjając wszystkim potrzebom człowieka, łaknąc szczęścia we wszystkich jego postaciach - oparła władzę na zasadach prawa. W obydwu sferach życia myśl okazała się silna i płodna; i tu, i tam nie brakowało rozumowi ludzkiemu wielkich natchnień, głębokich myśli i wzniosłych dzieł. Jako pierwszy wystąpił Wschód, ogarniając ziemię potokami światła, płynącymi z głębi jednolitej samoświadomości; następnie wkroczył Zachód, by swą wszechobejmującą działalnością, żywym słowem i potęgą analizy przejąć osiagnnięcia Wschodu, zakończyć rozpoczęte tam dzieła i wchłonąć je w swój szeroki zakres. Tymczasem pokorne umysły Wschodu, klęczące przed autorytetami historycznymi, wyczerpały swe siły w uległej służbie wobec świętej dla siebie zasady i zasnęły w końcu w swej nieruchomej syntetyczności, nie podejrzewając nowych losów, które im gotowano; tymczasem na Zachodzie umysły rozwijały się z dumą i swobodą, poddając się jedynie autorytetom rozumu i nieba, zatrzymując się tylko przed nieznanym, stale natomiast kierując wzrok ku nieogarnionej przyszłości. To nieprzerwane podążanie do przodu trwa, o czym wiecie, również dzisiaj; wiecie także, że od czasów Piotra Wielkiego i my sądzimy, że uczestniczymy w tym pochodzie" (Czaadajew, Apologia). 
prawdziwym sądem sumienia $\mathrm{w}$ wielu procesach toczących się przed wielkimi trybunałami ducha ludzkiego i społeczeństwa" (Czaadajew, Apologia).

Los Rosjan - w myśl czaadajewowskiego ujęcia - to dar opatrzności, lokującej ich $\mathrm{w}$ teleologicznie zorganizowanej przygodzie zwanej dziejami powszechnymi. Taka rama interpretacyjna pozwalała twierdzić, że przedstawiona koncepcja ma charakter zobiektywizowany - jest próbą oceny, w oparciu o spójny zestaw kryteriów, historycznej roli poszczególnych nacji. Narody i kultury, w myśl tego podejścia, wchodzą na scenę dziejową i schodzą z niej, czasowo dominując i w ten sposób przyczyniając się do rozwoju ludzkości. Pozornie, w obrębie takiego schematu, nie ma miejsca na sympatie i antypatie - chodzi o rzetelną i sprawiedliwą analizę dziejów oraz wskazywanie podmiotów, które w określonych epokach, spełniają funkcje szczególnie istotne. Dystans i spokój mędrca znikają jednak, gdy mowa o narodzie własnym. W oparciu o argumentację, którą można uznać za odmianę myślenia geopolitycznego, P. Czaadajew wyprowadził tezy, w świetle których przeszła słabość, to niezbity dowód przyszłej siły. A zatem, przeciwstawiając „zachodnie ucywilizowanie” oraz „rosyjską dzikość, zdawał się nie ulegać rezygnacji, lecz sugerował, że ten się śmieje, kto się śmieje ostatni. Zgodnie z opinią Osipa Emiljewicza Mandelsztama, cytowaną przez P. Mitznera, „Czaadajew uważał, że istnieje wielkie słowiańskie marzenie o powszechnym duchowym rozbrojeniu, po którym nastapi coś, co nazywane bywa pokojem" (cyt. za: Mitzner, 2012, s. 190).

Co zaskakujące, założenia z Apologii w znacznej mierze zbliżały się do stanowiska, które I. Kiriejewski przedstawił w młodzieńczym tekście Нечто о характере поэзии Пушкина [Kilka słów o charakterze poezji Puszkina] ${ }^{16}$. Lektura tego materiału przypomina, że jego autor, zanim stał się surowym krytykiem czaadajewszczyzny oraz jednym z przywódców ideowych słowianofilstwa, postrzegał Europę co najmniej dwupoziomowo. $\mathrm{Z}$ jednej strony jawiła mu się jako przestrzeń wielorakiego bogactwa, z którego bezdyskusyjnie należy czerpać. $Z$ drugiej - twierdził, że patrząc na narody Europy, z łatwością dostrzega się ich „wspólną fizjonomię”, nacechowaną długą pracą i mentalnym wyczerpaniem. Z tych względów, w mniemaniu I. Kiriejewskiego, wypada przyjąć, że Europa nie ma już sił, by się ratować. A zatem - wnioskował - o ile kultura europejska ma ocaleć, potrzebuje „,nowego serca”, którym może i powinien zostać naród rosyjski (Kiriejewski, Нечто).

${ }^{16}$ I. Kiriejewski pisał m.in.: „Время Чильд-Гарольдов, слава богу, еще не настало для нашего отечества: молодая Россия не участвовала в жизни западных государств, и народ, как человек, не стареется чужими опытами. Блестящее поприще открыто еще для русской деятельности; все роды искусств, все отрасли познаний еще остаются неусвоенными нашему отечеству; нам дано еще надеяться - что же делать у нас разочарованному Чильд-Гарольду?” [„Czas Childe-Haroldów, chwała Bogu, jeszcze w naszej ojczyźnie nie nastał: młoda Rosja nie uczestniczyła w życiu państw zachodnich, a naród, jak człowiek, nie starzeje się cudzymi doświadczeniami. Błyszcząca niwa stoi jeszcze otworem przed rosyjskim czynem; żadna dziedzina sztuk, żadna dziedzina poznania jeszcze nie została w naszej ojczyźnie przyswojona; dane nam jest jeszcze mieć nadzieję - więc cóż miałby porabiać u nas rozczarowany Childe-Harold?", tłum. B.H.] (Kiriejewski, Heymo). Tekst opublikowano na początku lat 30-tych w „Europejczyku”, w którym ukazał się również inny artykuł I. Kiriejewskiego. Pismo, podobnie jak „Teleskop” po publikacji P. Czaadajewa, zostało zamknięte. Sam car stwierdził, że teksty, które napisał I. Kiriejewski, wbrew profilowi periodyku okazały się politycznie zaangażowane i szkodliwe. W badaniach dotyczących dziejów rosyjskiej myśli XIX w. podnosi się, że trudno rozstrzygnąć, czy P. Czaadajew lub I. Kiriejewski inspirowali się swoimi tekstami (Christoff, 1972, s. 47-53). 
Wiara w opatrznościową misję Rosji, dobitnie i gromko wyrażona przez P. Czaadajewa, cieszyła się wielką popularnością wśród Rosjan przez całe XIX stulecie, a także później. Jej atrakcyjność była tak wielka, że zyskała ona status metazałożenia, przyjmowanego przez rzesze intelektualistów niezależnie od wyznawanego przez nich światopoglądu. Szeroko akceptowano oraz przepracowywano także motyw, zgodnie z którym poniżenie Rosji, dotykające ją cierpienia i nieszczęścia zwiastują jej przyszłą glorię. W ten sposób - co dobrze ilustruje poezja jednego z klasyków słowianofilstwa, Aleksego Chomiakowa - utrwalał się schemat myślowy, zgodnie z którym im Rosji powodzi się gorzej, tym w przyszłości będzie miała się lepiej ${ }^{17}$.

Obraz Rosji barbarzyńskiej, nieforemnej, amorficznej, młodej i nieokreślonej, nieokrzesanej, zapóźnionej, pogrążonej w wiecznym nieładzie przez stulecia silnie oddziaływał na rozwój stereotypów dotyczących rosyjskiego charakteru narodowego. Mniemania oparte na tym wyobrażeniu zawsze żywo interesowały Rosjan i w sporej mierze przyczyniły się do ich przeczulenia na punkcie własnego wizerunku. Wachlarz rosyjskich reakcji na spostrzeżenia dotyczące niecywilizowania Rosji należy uznać za bardzo szeroki. Niemniej wydaje się, że niezależnie od upływu czasu dominują tu dwa zjawiska. Po pierwsze, nie brakuje odniesień nacechowanych żalem, poczuciem krzywdy i niezrozumienia, pomieszanych z niechęcią czy wręcz lekceważeniem. Po drugie, zdarzały się i nadal zdarzają mniemania czy koncepcje, zgodnie z którymi rojenia o Rosji dzikiej i bezkształtnej ograniczają głównie tych, którzy je żywią, demonstrując zarazem m.in. naiwność, nadmierne zawężenie perspektywy, utratę poczucia realizmu, zaślepienie i/lub złą wolę.

$Z$ racji powyższych uwag, dyskusja na temat charakteru narodowego Rosjan nigdy nie przebiegała sielankowo. Niekiedy siła negatywnych emocji była tak duża, iż zarówno Rosjanie, jak i nie-Rosjanie wyrażali je skrajnie drastycznie. W XIX stuleciu jednym z chętnie eksploatowanych motywów był wątek gnicia organizmu społecznego.

Obecność tego motywu w debacie toczącej się w imperium Romanowów na ogół dokumentuje się wypowiedziami Konstantina Leontjewa (1831-1891), w świetle których życie organizmów kulturowych dzieli się na trzy fazy. W fazie pierwszej kultura jest pierwotnie niezróżnicowana, następuje natomiast inkubacja elementów, które rozwiną się później. Faza druga charakteryzuje się narastającym zróżnicowaniem kulturowym, kulminującym w momencie tzw. „,kwitnącej złożoności”, a scalanym przez „despotycz-

17 A. Walicki zwrócił uwagę, że często postawę, o której mowa, badacze charakteryzują przytaczając wiersz A. Chomiakowa Do Rosji, napisany w marcu 1854 r., a więc niedługo przed kampanią krymską. Tekst ten, silnie wobec Rosji krytyczny, piętnujący nieprawości drążące system mikołajowski, jest zarazem deklaracją wiary w świetlaną przyszłość narodu rosyjskiego. A. Chomiakow zarzucił w nim swojej ojczyźnie takie grzechy jak: „,czarną nieprawdę w sądach”, utrzymywanie ,jarzma niewolnictwa”, skłonność do „bezbożnych pochlebstw”, „kłamliwość”, „lenistwo”, przepełnienie „,wszelkim świństwem". Jednocześnie twierdził, że mimo tych wszystkich defektów, jego naród jest nadal narodem wybranym, powinien zatem się nawrócić i wołać do Boga o zmiłowanie. Skrucha i pokajanie, według poety, mogą i powinny zaowocować litością Boga oraz nowymi, wielkimi sukcesami ojczyzny. Podobny w wydźwięku jest również wcześniejszy wiersz A. Chomiakowa, o tym samym tytule, napisany w roku 1839. W tym utworze Rosja jawi się jako wybranka Boga, mająca do spełnienia misję, dzięki której świat ocali swoje dostojeństwo. Powinna zatem m.in. objawić innym narodom „miłość”, obwieścić „sakrament wolności”, „rozlać im blask wiary” (Chomiakow). 
ną jedność formy”. Faza trzecia - ,ponownego zmieszania i prostoty” - charakteryzuje się powtórnym uproszczeniem schematów kulturowych, ich rozkładem, który prowadzi do śmierci kultury.

U schyłku XIX w. - według K. Leontjewa - kulturą śmiertelnie chorą, gnijąca i generującą niezdrowe dla otoczenia wyziewy była Europa (Leontjew). Rosja, pozostając w jej sąsiedztwie, powinna separować się od niezdrowego europejskiego oddechu, czemu najlepiej służyć miała autokratyczna forma rządów („trzeba zamrozić Rosję, ażeby nie gniła") (cyt. za: Walicki, 2002, s. 382). W praktyce, w mniemaniu K. Leontjewa, należało ze wszelkich sił stopować liberalizm oraz egalitaryzm, będące dla niego sednem śmiertelnego schorzenia zabijającego europejskie nacje. K. Leontjew twierdził, że właśnie zmiany liberalno-egalitarne są ,,antytezą procesu rozwoju”. W jego opinii, „W procesie rozwoju idea wewnętrzna mocno trzyma materię społeczną w swych organizujących, despotycznych objęciach i ogranicza jej rozbieżne, odśrodkowe tendencje. Natomiast postęp walczący z wszelkim despotyzmem - despotyzmem stanów, cechów, klasztorów, a nawet bogactwa - jest niczym innym, jak procesem rozkładu, procesem owego powtórnego uproszczenia całości i mieszania ze sobą części składowych" (cyt. za: Walicki, 2002, s. 381-382).

Zauważmy, że popularną pozostaje także wypowiedź Mikołaja Aleksandrowicza Dobrolubowa (1836-1861). Autor ten w recenzji z 1859 r. diagnozował, że w Rosji istnieją dwa stronnictwa. Pierwsze z nich krzyczeć miało „Rosja kwitnie, Zachód gnije”, drugie „Rosja gnije, Zachód kwitnie” (Dobrolubow).

Niemniej, w świetle uwag I. Grudzińskiej-Gross, wypada pamiętać, że również ludzie Zachodu w XIX stuleciu chętnie operowali metaforą kultury gnijącej, rozkładającego się narodu czy społeczeństwa. Zgodnie z uwagami tej autorki, Rosję - podobnie jak Amerykę - traktowano nieraz ,jako naród zbyt młody, ale już u schyłku”, który „przegnił, zanim dojrzał” (Grudzińska-Gross, 2010, s. 79-80). Nie sposób nie wspomnieć również, że w ówczesnej Europie nierzadkim było wyobrażenie Rosji jako trupa, który nie rozkłada się tylko dlatego, że jest zamrożony. Ten obraz funkcjonował również w przestrzeni poglądów na temat właściwego zarządzania narodami. Na jego gruncie usiłowano uzasadnić m.in. mniemanie, w myśl którego Rosja jest i musi pozostać rządzona despotycznie. Car pełnić miałby tutaj rolę surowego, północnego wiatru, który dmąc w przestronnych, lecz martwych przestrzeniach rosyjskiej mentalności, zmraża ją i zapobiega m.in. przedostawaniu się trupiego fetoru na Zachód.

Obecność, popularność oraz wieloznaczność omówionej oraz podobnych analogii przyczyniły się do upowszechnienia poglądu o nieusuwalnym niedopasowaniu Rosji i Zachodu. Na kanwie tego typu wyobrażeń przez stulecia narastały przesłanki głębokiej niechęci pomiędzy obiema przestrzeniami kulturowymi. Na tle licznych wypowiedzi wyrażających wzajemne uprzedzenia, a nawet wzgardę, widać wyraźnie, jak w stosunkach Rosjan z reprezentantami narodów europejskich, mimo nie tak znów rzadkiej, wzajemnej fascynacji, wielokrotnie górę brały konflikty interesów, animozje związane z niełatwą przeszłością oraz dystans kulturowy. W XIX w. wszystkie wymienione bariery - $\mathrm{w}$ powiązaniu $\mathrm{z}$ gwałtownym przyspieszeniem procesów historycznych, w tym z intensyfikacją kontaktów międzynarodowych - nieraz sprzyjały generowaniu strachu, nieufności, niefortunnych wypowiedzi, urażonej dumy, wzgardy i chęci odwetu. 


\section{Bibliografia}

Andrusiewicz A. (1994), Mit Rosji, t. 2, Wydawnictwo Wyższej Szkoły Pedagogicznej, Rzeszów.

Baszkiewicz J. (2009), Świat wartości i świat symboli, w: idem, Państwo - rewolucja - kultura polityczna, oprac. H. Olszewski, Wydawnictwo Poznańskie, Poznań.

Berlin I. (2003), Rosja i rok 1848, w: idem, Rosyjscy myśliciele, Prószyński i S-ka, Warszawa.

Bezwiński A. (1980), Czaadajew i Schelling. O korespondencji dwóch filozofów, „Studia Filologiczne. Filologia rosyjska. Zeszyty Naukowe WSP”, z. 7.

Bezwiński A. (1983), Prawosławie czy katolicyzm? Próba odpowiedzi Piotra Czaadajewa i Iwana Kiriejewskiego, „Studia Filologiczne. Filologia rosyjska. Zeszyty Naukowe WSP”, z. 18.

Bierdiajew M. (1999), Rosyjska idea, Biblioteka Frondy, Warszawa.

Chojnicka K. (1983), Konserwatysta w stużbie rewolucji, „Tu i Teraz”, nr 50.

Chomiakow A., Стихотворения, http://az.lib.ru/h/homjakow_a_s/text_0010.shtml.

Christoff P. K. (1972), An Introduction to Nineteenth-Century Russian Slavophilism, vol. 2 (I. V. Kireevskij), The Hague, Mouton.

Czaadajew P. (1961), Brak historii jako nieszczęście Rosji, w: Filozofia i myśl społeczna rosyjska 1825-1861, oprac. A. Walicki, PWN, Warszawa.

Czaadajew P. (1992), Listy, przeł. M. Leśniewska i L. Suchanek; wstęp L. Suchanek, Uniwersytet Jagielloński, Kraków.

Czaadajew P., Философические письма, „Biblioteka Maksyma Moszkowa”, http://az.lib.ru/c/chaadaew_p_j/text_0010.shtml.

Czaadajew P. J. (1991), Полное собрание сочинений и избранные писма, t. 1-2, Изд-во: Наука, Moskwa.

Czaadajew, Apologia obłakanego, tłum. J. Dobieszewski, http://historia.upjp2.edu.pl/pro_instytut/zasoby/files/apologia_oblakanego_czaadajew.pdf.

de Custine A. (1995), Rosja w roku 1839, t. 1-2, Warszawa 1995.

de Lazari A. (1995), Mesjanizm/misjonizm, kolektywizm, w: idem, Mentalność rosyjska. Słownik, Śląsk, Katowice.

de Lazari A. (1996), Czy Moskwa będzie Trzecim Rzymem? Studia o nacjonalizmie rosyjskim, Śląsk, Katowice.

de Lazari A. (red.) (2004), Dusza polska i rosyjska od Adama Mickiewicza i Aleksandra Puszkina do Czestawa Miłosza i Aleksandra Solżenicyna. Materiały do katalogu nieufności Polaków i Rosjan, Polski Instytut Spraw Międzynarodowy, Warszawa.

Dobieszewski J. (1986), Filozofia społeczna Piotra Czaadajewa, „Studia Filozoficzne”, nr 7.

Dobieszewski J. (1986), Przeciwieństwo między Rosja a Europq jako teoria, „Studia Filozoficzne”, nr 8.

Dobrolubow М., От Москвы до Лейпцига. И. Бабста, w: idem, Рецензии, http://az.lib.ru/d/dobroljubow_n_a/text_0760.shtml.

Drozdowicz Z. (1991), Główne nurty w nowożytnej filozofii francuskiej, Wydawnictwo Naukowe UAM, Poznań.

Figes O. (2002), Taniec Nataszy. Z dziejów kultury rosyjskiej, Wydawnictwo Magnum, Warszawa.

Grudzińska-Gross I. (2000), Piętno rewolucji. Custine, Tocqueville, Mickiewicz i wyobraźnia romantyczna, PWN, Warszawa.

Hercen A. (1966), Eseje filozoficzne, t. 2: Rosja i stary świat, PWN, Warszawa.

Herling-Grudziński G. (1989), Dziennik pisany nocq 1971-1972, cyt. za: A. de Custine (1989), Listy z Rosji. Rosja w 1839 roku, Aramis, Kraków.

Kiriejewski I., Нечто о характере поэзии Пушкина, http://az.lib.ru/k/kireewskij_i_w/text_0070.shtml. 
Kiriejewski Р. (1998), Писмо к Н. М. Языкову (отрывок), w: В. Чернецов, П. Я. Чаадаев: pro et contra, Издательство Русского Христианского Гуманитарного Института, Sankt Petersburg.

Leontjew K., Византизм и славянство, http://az.lib.ru/l/leontxew_k_n/text_0100.shtml.

Massaka I. (2001), Eurazjatyzm. Z dziejów rosyjskiego misjonizmu, Fundacja na Rzecz Nauki Polskiej, Wrocław.

McNally R. (1971), Chaadaev and his Friends: An Intellectual History of Peter Chaadaev and His Russian Contemporaries, Diplomatic Press, Tallahassee.

Miłosz Cz. (2010), Rosja, w: idem, Rosja. Widzenia transoceaniczne, t. I, „Zeszyty Literackie”, Warszawa.

Mitzner P. (2012), Droga do Rosji, Oficyna Wydawnicza Errata, Warszawa.

Mucha B. (1995), W kręgu rosyjskich katolików i filokatolików, Wydawn. Uniwersytetu Łódzkiego, Łódź.

Muhlstein A. (2001), Astolphe de Custine: The Last French Aristocrat, Duckworth, London.

Nikitienko A. (1998), Дневник (отрывок), w: В. Чернецов, П. Я. Чаадаев: pro et contra, Издательство Русского Христианского Гуманитарного Института, Sankt Petersburg.

Première lettre philosophique adressée à une dame, w: „La bibliothèque des introuvables: linguistique générale et slave, et autres merveilles", http://www2.unil.ch/slav/ling/textes/ChaadaevPremlettrephilo.html.

Przebinda G. (1997), Apologia obłakanego Piotra Czaadajewa, „Acta Polono-Ruthenica II”.

Przebinda G. (1998), Od Czaadajewa do Bierdiajewa. Spór o Boga i człowieka w myśli rosyjskiej (1832-1922), PAU, Kraków.

Przebinda G. (2003), Narodziny filozofa w Rosji. Czaadajew przed 1828 rokiem; Czaadajew - ojciec prowidencjalizmu w Rosji, w: idem, Między Moskwq a Rzymem. Myśl religijna w Rosji XIX i XX wieku, Universitas, Kraków.

Walicki A. (1970), Filozofia a mesjanizm. Studia z dziejów filozofii i myśli społeczno-religijnej romantyzmu polskiego, PIW, Warszawa.

Walicki A. (2002), W kręu konserwatywnej utopii. Struktura i przemiany rosyjskiego słowianofilstwa, PWN, Warszawa.

Walicki A. (2005), Zarys myśli rosyjskiej. Od Oświecenia do Renesansu religijno-filozoficznego, Wydawnictwo Uniwersytetu Jagiellońskiego, Kraków.

Гершензон М. О. (1908), П. Я. Чаадаев: Жизнь и мышление, Тип. М. М. Стасюлевича, Sankt Petersburg.

Де Кюстин А. (1996), Россия в 1839 году, Изд-во им. Сабашниковых, Moskwa.

Доклад следственной комиссии от 28 ноября 1836 г. (заключителная часть), w: В. Чернецов, П. Я. Чаaдаев: pro et contra, Издательство Русского Христианского Гуманитарного Института, Sankt Petersburg.

Кожинов В., Маркиз де Кюстин как восхищённый созериатель России, http://www.patriotica.ru/ enemy/kozh_kustin.html.

Мильчина В., Несколько слов о маркизе де Кюстине, его книге и ее первых русских читателях, http://www.hrono.ru/libris/lib_k/kus_prim1.php.

Мяло К., Хождение к варварам или вечное путешествие маркиза де Кюстина, http://www.pseudology.org/Literature/HozhdenieMyalo.htm.

Сапов В. (1991), Литература о П. Я. Чаадаеве (Избранная библиография), w: П. Я. Чаадаев, Полное собрание сочинений и избранные письма, t. 2, Изд-во: Наука, Moskwa.

Чернецов В. (1998), П. Я. Чаадаев: pro et contra, Издательство Русского Христианского Гуманитарного Института, Sankt Petersburg. 


\section{The motif of Russian indefiniteness as an element of the 19th-century political narrations}

\section{Summary}

The 19th-century popularity and ambiguity of many versions of the motif of Russian indefiniteness contributed to popularize the view about its ineffaceable incongruity to the West. On the basis of such ideas the premises of the deep aversion between these two spheres were arising. Against this background, it is clearly visible why despite of the not so rare mutual fascination, the relations between Russians and other European nations were often dominated by conflicts of interests, animosities and embarrassment associated with the difficult past and cultural distance. All of these barriers - in conjunction with the rapid acceleration of historical processes, including the intensification of international contacts - were facilitating the creation of fear, distrust, unfortunate statements, wounded pride, contempt and desire for revenge.

Key words: Russia as an object of political narrations, the motif of Russian indefiniteness, Astolphe de Custine, Pyotr Chaadaev 
